
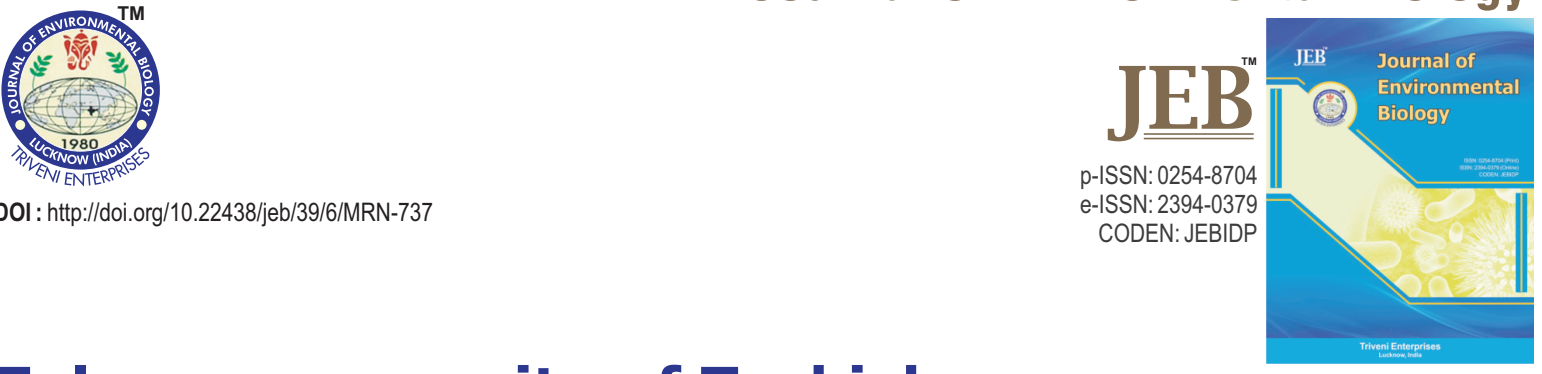

\title{
Tolerance capacity of Turkish genotypes of barley (Hordeum vulagare L.) for cadmium stress
}

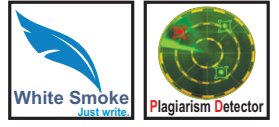

Authors Info

M.K.A. Ansari ${ }^{1,2}$, A. Ahmad ${ }^{3}$, I.M. Aref, G. Owens ${ }^{5}$ and M. Iqbal ${ }^{6 *}$ 'Cyanobacterial Biotechnology Laboratory, Department of Biosciences, Faculty of Natural Sciences, Jamia Millia Islamia, New Delhi -110 025, India

${ }^{2}$ Molecular Biology Laboratory, Department of Biology, Faculty of Science, Andolu University, Eskisehir, 26470, Turkey

${ }^{3}$ Nanobiotechnology Laboratory, Department of Botany, Faculty of Life Sciences, Aligarh Muslim University, Aligarh -202 002, India

${ }^{4}$ Department of Plant Production, College of Food \& Agricultural Sciences, King Saud University, Riyadh-11451, Saudi Arabia

${ }^{5}$ Environmental Contaminants Group, Mawson Institute, University of South Australia, Mawson Lakes - 5095, Australia

${ }^{6}$ Molecular Ecology Laboratory, Departmen of Botany, Faculty of Science, Hamdard University, New Delhi -110 062, India

${ }^{*}$ Corresponding Author Email : iqbalg5@yahoo.co.in

Key words

Cadmium stress

Genotype screening

Hordeum vulgare

Seed germination

Seedling growth

Publication Info

Paper received : 30.08 .2017

Revised received: 16.12.2017

Accepted: 19.02.2018

\section{Abstract}

Aim : Elevated levels of heavy metals in agricultural soils result in significant contamination of food in Turkey, where cadmium toxicity is currently one of the most serious environmental issues. This study was undertaken to screen the various Turkish genotypes of barley for their sensitivity/tolerance towards cadmium stress.

Methodology : Short-term experiments involving plant exposure to different $\mathrm{Cd}$ concentrations $(0-100 \mu \mathrm{M})$ were conducted to evaluate the response of ten barley genotypes (viz., Aydanhanım, Bilgi91, Çildir-02, Erginel-90, Ince-04, Kalayci97, Keser, Larende, Özdemir-05, Tarm-92) under hydroponic conditions. Seed germination, seedling growth and $\mathrm{Cd}$ accumulation in plant tissues were taken as the criteria to evaluate the comparative genotypic response to $C d$ stress.

Results : Cd-induced stress significantly decreased seed germination percentage in all genotypes and the effect was dosedependent. At $100 \mu \mathrm{M} \mathrm{Cd}$ stress, genotypes Keser and Aydanhanim showed the maximum (46\%) and minimum (12\%) loss respectively, compared with the control. Root length was reduced by $68 \%$ and $30 \%$, while shoot length declined by $44 \%$ and $11 \%$ in these genotypes, respectively. Similarly, the loss of root and shoot biomass was maximum in genotype Keser and minimum in Aydanhanim. However, genotype Aydanhanim accumulated the maximum $\left(5.96 \mathrm{\mu g} \mathrm{g}^{-1}\right.$ d.wt.), whereas Keser retained the minimum ( $5.41 \mu^{-1} \mathrm{~g}^{-1} \mathrm{~d}$. wt.) amount of $\mathrm{Cd}$ in

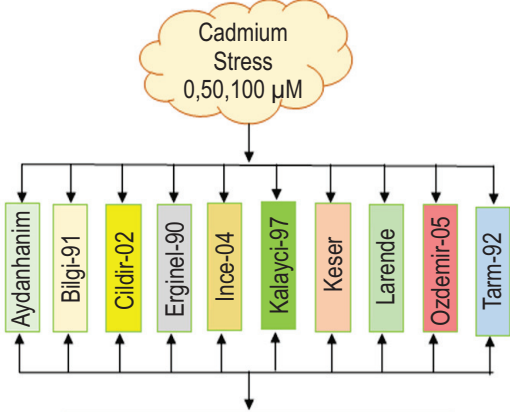

$100 \mu \mathrm{M}$ Dose Most Effective

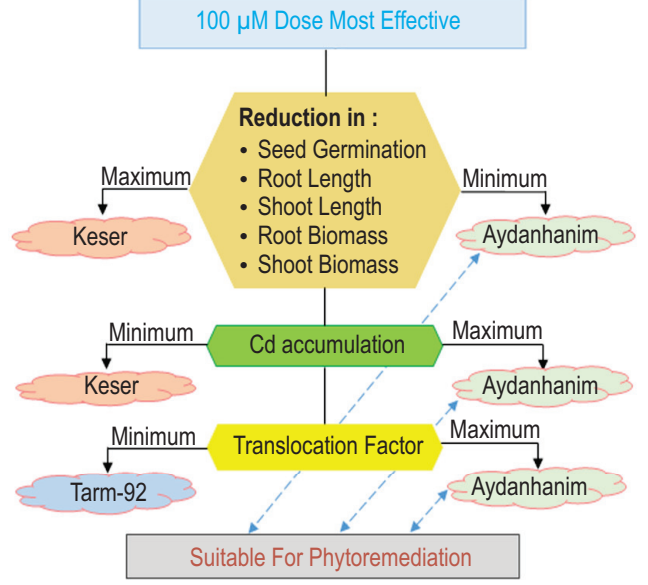
their roots at $100 \mu \mathrm{M}$. Cd accumulation in shoot also displayed a similar genotypic difference.

Interpretation : Based on the above observations, Aydanhanım was Cd-tolerant, while Keser was most susceptible among the genotypes studied. Thus, genotype Aydanhanim has a promise to be a suitable candidate for phytoremediation of $\mathrm{Cd}$-contaminated sites. 


\section{Introduction}

Unplanned urbanization and rapidly expanding industrialization in developing countries have resulted in huge heavy metal discharges into the environment over the last few decades, thus posing a potential threat to ecosystems and human health (Mahmood et al., 2012; Wang et al., 2017). Heavy metals present in soils and/or waters are not degraded by biological or chemical processes, hence persist for long periods of time and are often taken up by plants grown in that environment (Iqbal et al., 2015). The surface and ground waters, containing elevated levels of heavy metal are sometimes used as a source of drinking water and pose threat to fresh water ecosystems and human populations (Akbulut and Tuncer, 2011).

Cadmium, has contaminated the agricultural soil and become a critical environmental concern due to its potential adverse ecological effects. The regulatory limit of $\mathrm{Cd}$ for agricultural soils is $100 \mathrm{mg} \mathrm{kg}^{-1}$ soil (Salt et al., 1995), although this threshold has been exceeded due to a variety of anthropogenic activities (Kalai et al., 2014). Cd is a non-essential element for crop plants, but is readily taken up by the plants growing on $\mathrm{Cd}$ contaminated soils and thus, enters the food chain (Fischer, 2005; Long et al., 2013). Elevated Cd concentrations cause a number of quantifiable toxic symptoms in plants, e.g. they inhibit seed germination and seedling growth (Jaouani et al., 2016), photosynthetic process, chlorophyll biosynthesis and nitrate reductase activity (Ali et al., 2000, 2001; Mobin, 2013; Bashir et al., 2015), and can alter even the morphological and anatomical characteristics of plants (Mehindirata et al., 1999, 2000; Khudsar et al., 2000, 2001; Ahmad et al., 2005). This leads to a decline in crop productivity (Vassilev et al., 1998; Anjum et al., 2014) and eventually to the death of the plant (Nagajyoti et al., 2010). Cadmium accumulation alters the mineral-nutrients uptake, inhibits the stomatal opening by interacting with water balance of the plant, and disturbs the Calvin cycle enzymes, carbohydrate metabolism and antioxidant system (Nazar et al., 2012; Anjum et al., 2008a, 2011). Crop tolerance to $\mathrm{Cd}$ toxicity depends on the crop's ability to absorb $\mathrm{Cd}$ ions. Cadmium interacts with the available soil nutrients some of which also have a protective role against the toxic effects of Cd stress (Ali et al., 1998a, 1998b; Nazar et al., 2012). For instance, the relationship between $\mathrm{Cd}$ and $\mathrm{Zn}$ in plants with reference to their uptake, translocation and remobilization is very complex. They have similar ionic structures and electro-negativities, but different ionic radii $\left(\mathrm{Zn}^{2+}=0.074 \mathrm{~nm}\right.$, $\mathrm{Cd}^{2+}=0.097 \mathrm{~nm}$ ), which might correlate to plant selectivity (El-Kafafi and Rizk, 2013). The reduction in Cd uptake caused by Zn fertilization might be due to the competitive transport and absorption interaction between these two ions.

Barley (Hordeum valgare L.), a staple food in many parts of the world and the fourth largest cereal crop cultivated and consumed worldwide, is an ideal model crop for hereditary and physiological studies (Forster et al., 2000). Owing to a rapid loss of genetic difference through genotype replacement, barley genotypes have become more sensitive to environmental stress
(Ahmed et al., 2013). Identification of such native barley plants that possess $\mathrm{Cd}$ tolerance and accumulation traits should help in the selection, breeding or genetic engineering of the future crops that are capable of growing in the contaminated environments and remediating the $\mathrm{Cd}$-contaminated soils with lesser risk of food-chain contamination. It is, therefore, important to know the level of resistance to $\mathrm{Cd}$ toxicity in various genotypes and their capacity to accumulate $\mathrm{Cd}$.

Most of the methods available for screening the heavymetal-tolerant plants are expensive and time-consuming. Screening of a large number of genotypes in the field often suffers from spatial heterogeneity of chemical and physical properties of the soil and from seasonal fluctuations in rainfall, humidity and temperature (Mahmood, 2009). For mass screening, hydroponics-based nutrient-solution culture is an efficient and cost-effective technique, as it provides an easy access to plantroot system and a better control of nutrient management with a uniform distribution of the stressor in the nutrient media (Ansari et al., 2015), although, on the other hand, the sand-culture method may predict field results more accurately.

The present study, carried out through a hydroponic culture, is a maiden attempt to screen the various Turkish genotypes of barley for their sensitivity towards $\mathrm{Cd}$ stress. It is focused on seed germination, seedling growth and $\mathrm{Cd}$ accumulation in ten barley genotypes with an aim to determine their tolerance capacity for the cadmium stress.

\section{Materials and Methods}

Seed germination and seedling growth : Seeds of ten genotypes of barley (Hordeum vulgare L.), viz., Aydanhanım, Bilgi-91, Çildir-02, Erginel-90, İnce-04, Kalayci-97, Keser, Larende, Ozdemir-05 and Tarm-92, were procured from the Transitional Zone Agricultural Research Institute, Eskisehir, Turkey, and germinated hydroponically on Whatman filter papers (\#42) soaked with $3 \mathrm{ml}$ distilled water and with $3 \mathrm{ml}$ of aqueous solutions of 50 and $100 \mu \mathrm{M}$ of $\mathrm{Cd}\left(\mathrm{as} \mathrm{CdCl}_{2}\right.$ ) and placed in separate Petri dishes (diameter $100 \mathrm{~mm}$, height 25 $\mathrm{mm}$ ) kept in the dark for 3 days in a growth chamber maintained at $25^{\circ} \mathrm{C}$. Fifteen seeds were placed in each Petri dish and each treatment was replicated thrice. The seeds were considered germinated when both plumule and radicle were extended from their junction. Seeds were counted after 10 days for calculating the germination percentage.

In another set of experiment, small seedlings were transferred, three days after germination, to plastic beakers containing $250 \mathrm{ml}$ of nutrient solution, which consisted of $3 \mathrm{mM}$ $\mathrm{KNO}_{3}, 2 \mathrm{mM} \mathrm{Ca}\left(\mathrm{NO}_{3}\right)_{2}, 1 \mathrm{mM} \mathrm{NH}_{4} \mathrm{H}_{3} \mathrm{PO}_{4}, 50 \mu \mathrm{M} \mathrm{KCl}, 25 \mu \mathrm{M}$ $\mathrm{H}_{3} \mathrm{BO}_{3}, 2 \mu \mathrm{M} \mathrm{MnCl}_{2}, 2 \mu \mathrm{M} \mathrm{ZnCl}_{2}, 0.5 \mu \mathrm{M} \mathrm{CuCl}_{2}, 0.5 \mu \mathrm{M}\left(\mathrm{NH}_{4}\right)_{6}$ $\mathrm{MO}_{7} \mathrm{O}_{24}, 20 \mu \mathrm{M} \mathrm{Na}_{2}$ Fe-EDTA and $1 \mathrm{mM} \mathrm{MgSO}_{4}$. Concentration of $\mathrm{Mg}^{2+}$ was maintained at $1 \mathrm{mM}$ by subsequent addition of $\mathrm{MgCl}_{2}$ and $\mathrm{pH}$ of the solution was adjusted to $6.5 \pm 0.1$ with $0.1 \mathrm{M} \mathrm{NaOH}$. The nutrient solution was aerated continuously with sterile air and 
replaced weekly. After 10 days growth, 0,50 and $100 \mu \mathrm{M} \mathrm{Cd}$ (as $\mathrm{CdCl}_{2}$ ) solutions were added to the nutrient solution. One set of seedlings (with $0 \mu \mathrm{M}$ added $\mathrm{Cd}$ ) served as the control. All the seedlings were exposed to a photosynthetic photon flux density of $200 \mu \mathrm{mol} \mathrm{m} \mathrm{s}^{-2}$ using a combination of fluorescent tubes and tungsten lamps under a $16 \mathrm{hr}$ photoperiod.

The seedlings were harvested 10 days after the application of $\mathrm{Cd}$ and washed thoroughly with sterilized distilled water before further analysis. The length of shoots and roots was measured using a $30 \mathrm{~cm}$ ruler. The shoots and roots were separated and oven-dried at $70^{\circ} \mathrm{C}$ for $72 \mathrm{hrs}$ and then weighed. The dried biomass was subsequently ground with a stainless steel grinder and passed through a 100-mesh sieve prior to estimating the $\mathrm{Cd}$ content in plant parts.

Analysis of cadmium : Cadmium content in roots and shoots was determined following the digestion of dried plant material. The harvested plant parts were washed thoroughly with Milli-Q water (resistivity $>18 \mathrm{M} \Omega . \mathrm{cm}$ at $25^{\circ} \mathrm{C}$ ), dried at $70 \pm 2^{\circ} \mathrm{C}$ for 72 $\mathrm{hrs}$, ground to a fine powder and digested in a sulfuric acid/nitric acid mixture (2:1, v/v), following the method of Piper (1942). Dried material $(0.25 \mathrm{~g})$ from each treatment was gently swirled with concentrated $\mathrm{HNO}_{3}(3 \mathrm{ml})$ in a $50 \mathrm{ml}$ digestion tube on a heating block maintained at $150^{\circ} \mathrm{C}$ for one hr. Digestion tubes were then cooled to room temperature and $30 \% \mathrm{H}_{2} \mathrm{O}_{2}(2 \mathrm{ml})$ was added. Heating was continued for an additional $3 \mathrm{hrs}$ at $150^{\circ} \mathrm{C}$ and thereafter, cooled to room temperature. The digested plant solution was diluted to $50 \mathrm{ml}$ and the supernatant was analyzed for $\mathrm{Cd}$ content, using an atomic absorption spectrometer (ZEEnit 65 , Analytik Jena, Germany) fitted with a Wall type graphite tube.

Statistical analysis : All the values were the means $(n=9)$ of three independent runs of the experiments with three replications in each run. A two-way ANOVA test was used to confirm the significance of the data. Comparison with the control and among treatments was done using the Duncan's multiple range test. To determine whether differences between treatments were significant relative to the control, least significant difference (LSD, $\mathrm{p} \leq 05)$ was determined.

\section{Results and Discussion}

Seed germination, i.e., emergence of radicle from testa as visible to eye, was recorded and expressed as percentage, with the control having $100 \%$ germination. Cd stress inhibited seed germination in all the genotypes screened. The maximum effect appeared under the influence of $100 \mu \mathrm{M}$, wherein 13 seeds (out of 15 seeds tested) germinated in the case of genotype Aydanhanim and only 11 in the case of Keser. The decline in seed germination with reference to the control was significant and dose-dependent and varied in different genotypes from 12\% (Aydanhanim) to 46\% (Keser) (Fig. 1).

Plant sensitivity to toxic metals is influenced not only by the concentration and type of the toxicant, but also by the developmental stage of the plant (Kalai et al., 2014). Seed germination, one of the most sensitive physiological stages in

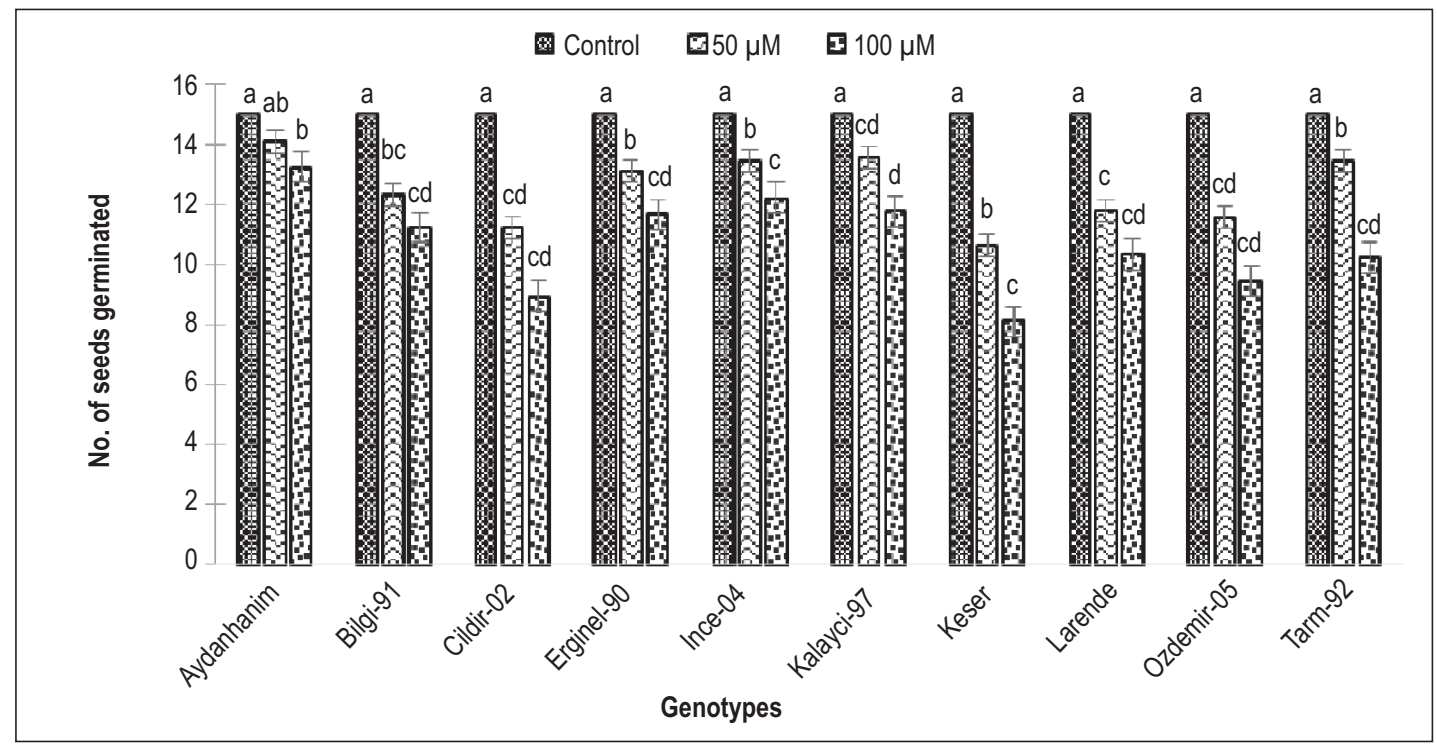

Fig. 1 : Seed germination in different barley genotypes growing under Cd stress $(0-100 \mu \mathrm{M})$. All values are means of three independent experiments with three replicates $(n=9)$. Vertical lines indicate \pm SE. The bars bearing different letters are statistically different at $p \leq 0.5$, as determined by the Duncan's Multiple Range Test. 
plant growth, starts with water absorption by mature seeds and ends with the protraction of embryonic axis and the appearance of radicle through seed coats (Rajjou et al., 2012). At the cellular level, seed germination is basically characterized by the resumption of respiratory activity through reactivation of glycolysis, Krebs cycle and respiratory chain (Müntz et al., 2001); reserves mobilization via secretion of hydrolytic enzymes (SfaxiBousbih et al., 2010), de-polymerization of reserves, and transport of metabolites released into the growing embryonic cells (Smiri et al., 2009); and reduction in the strength of tissues

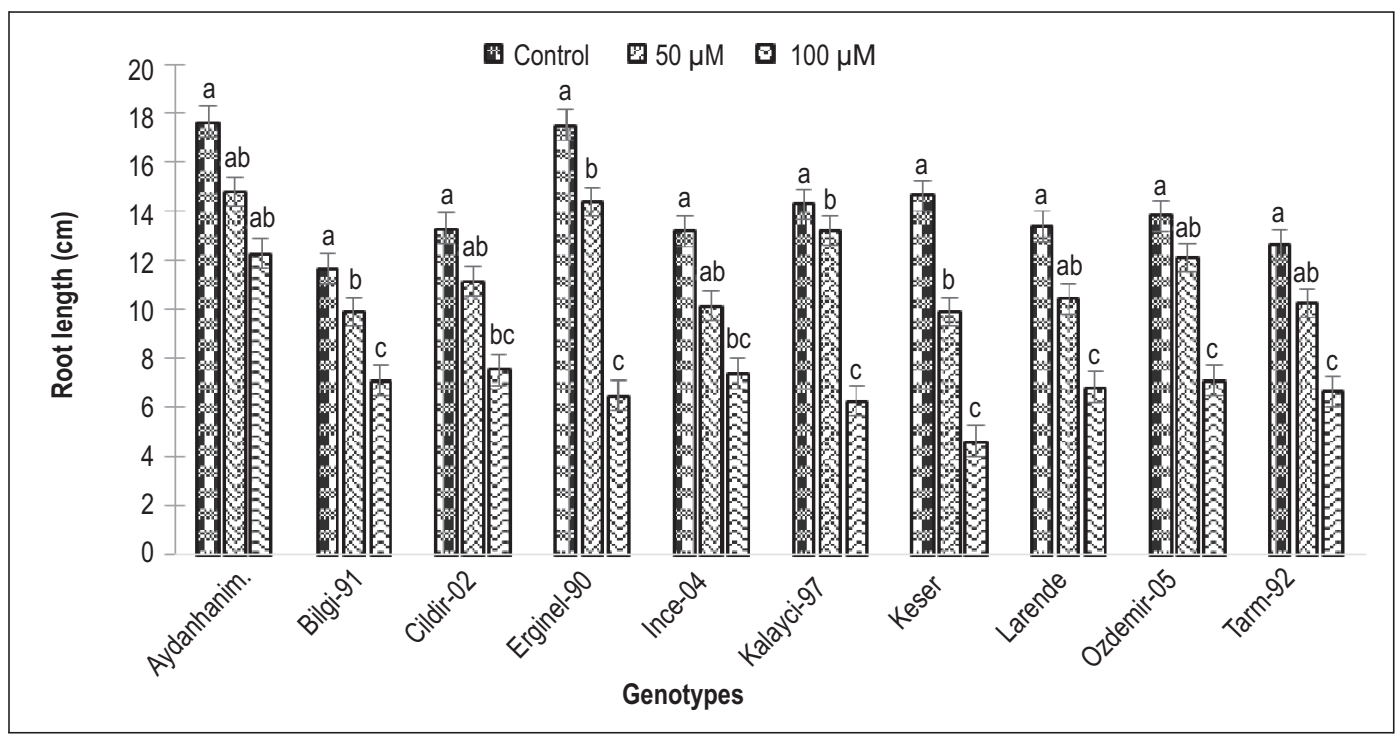

Fig. 2 : Root length of 20-day-old seedlings of barley genotypes growing under $\mathrm{Cd}$ stress $(0-100 \mu \mathrm{M})$. All values are means of three independent experiments with three replications each $(n=9)$. Vertical lines indicate $\pm S E$. The bars bearing different letters are statistically different at $p \leq 0.5$, as determined by the Duncan's Multiple Range Test.

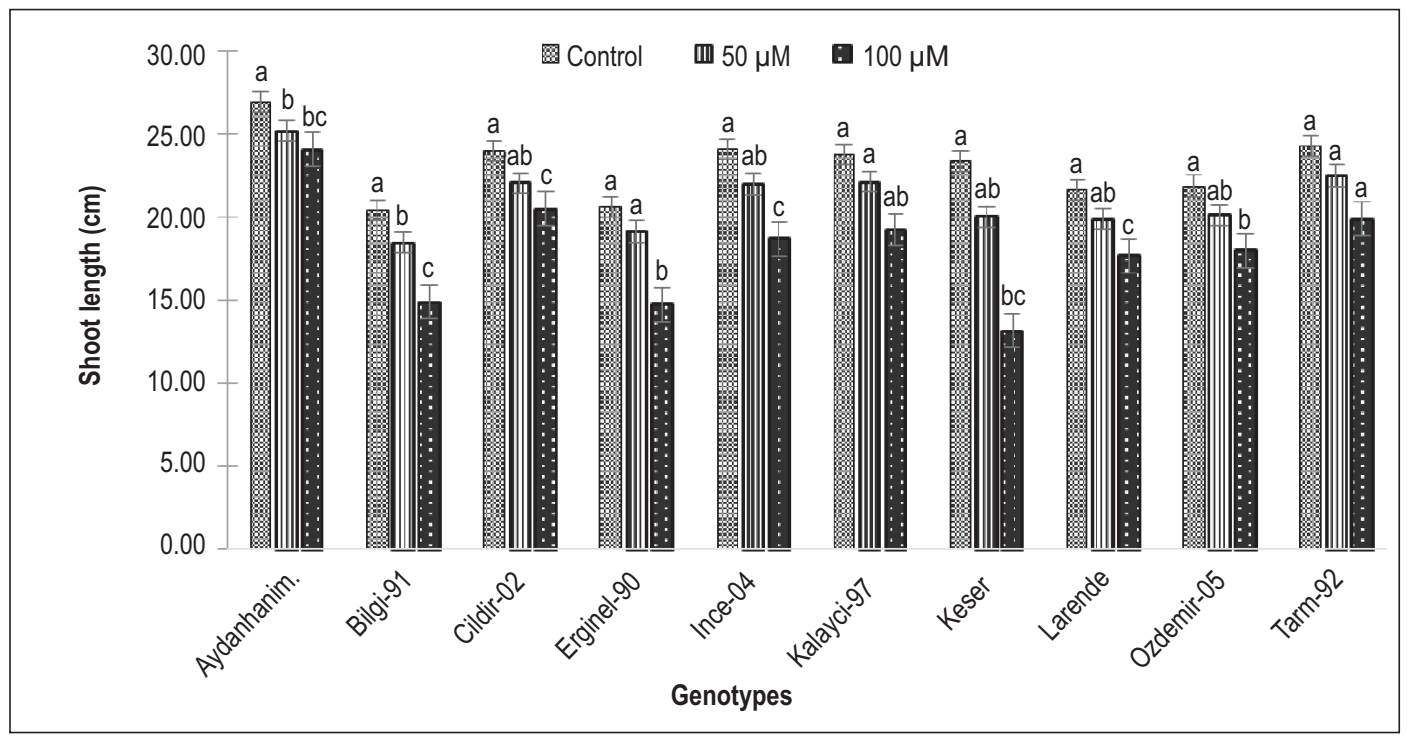

Fig. 3 : Shoot length of 20-day-old seedlings of barley genotypes growing under $\mathrm{Cd}$ stress $(0-100 \mu \mathrm{M})$. All values are means of three independent experiments with three replications each $(n=9)$. Vertical lines indicate $\pm S E$. The bars bearing different letters are statistically different at $p \leq 0.5$, as determined by the Duncan's Multiple Range Test. 


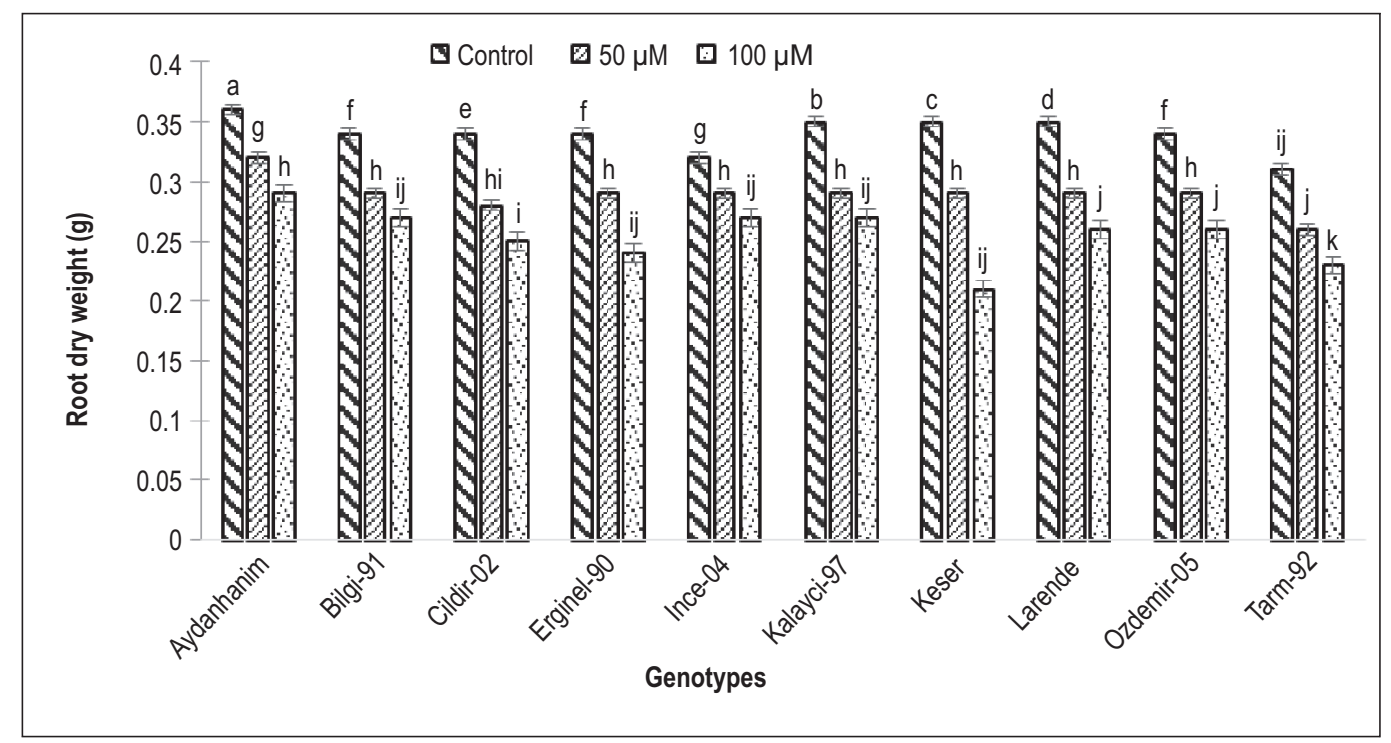

Fig. 4 : Root dry weight of 20-day-old seedlings of barley genotypes growing under $\mathrm{Cd}$ stress $(0-100 \mu \mathrm{M})$. All values are means of three independent experiments with three replications each $(n=9)$. Vertical lines indicate $\pm S E$. The bars bearing different letters are statistically different at $p \leq 0.5$, as determined by the Duncan's Multiple Range Test.

surrounding the embryo, mainly due to increased activity of cell wall hydrolases (Kalai et al., 2014). Moreover, seed germination relies almost exclusively on seed reserves for the supply of metabolites for respiration as well as other anabolic reactions. The available evidences indicates that starch, the most abundant storage material in seeds, is degraded in germinating seeds predominantly via the amylolytic pathway (Dua and Sawhney, 1991; Ansari et al., 2013). Seed coat provides some protection from the metal stress prior to germination, but eventually cracks or becomes more permeable upon germination. Inhibition of seed germination depends, however, on type and concentration of the metal used, duration of seed exposure, plant species and grain integuments (Munzuroglu and Geckil, 2002). In germinating pea seeds, the cadmium-induced oxidative stress was resisted initially by embryos for few days, beyond which severe metabolic disturbances started, followed by protein damage, structural disruption of membranes and a disturbed cellular homeostasis, possibly due to failure of antioxidant defence system; these developments inhibited the embryonic growth (Jaouani et al., 2016). Cadmium also inhibits the activity of enzymes such as alcohol dehydrogenase, hexokinase and glucose-6-phosphate dehydrogenase, as observed in germinated seeds of Pisum sativum (Munzuroglu and Zengin, 2006).

Metals affect seed germination by inhibiting the water uptake and disturbing the various nutritional mechanisms. Although seeds are well-protected against stresses, soon after imbibition and protrusion of embryonic axis, they become stress sensitive (Kuriakose and Prasad, 2008). In this study, seed germination was most efficient in genotype Aydanhanim and poorest in genotype Keser because the seed coats degraded quicker in the latter genotype than in the former. In short, the greater inhibition of seed germination in Keser than in Aydanhanim could be due to the suppression of water uptake or an earlier cracking of seed coat, thus causing a differential genotypic resistance to $\mathrm{Cd}$ toxicity.

Plant-growth inhibition due to $\mathrm{Cd}$ stress was observed, in this study, with a considerable decline in root length, shoot length and biomass accumulation in a dose-dependent manner maximum occurring at $100 \mu \mathrm{M}$ dose. The root length in genotype Aydanhanim measured about $17 \mathrm{~cm}$ in the control population and $12 \mathrm{~cm}$ under $100 \mu \mathrm{M}$ Cd stress, while the Keser roots measured about $11 \mathrm{~cm}$ and $5 \mathrm{~cm}$ at $0 \mu \mathrm{M}$ and $100 \mu \mathrm{M}$, respectively (Fig. 2), showing that the reduction in the root length caused by $100 \mu \mathrm{M} \mathrm{Cd}$ varied between 30\% (Aydanhanim) and 68\% (Keser) with respect to the control. Likewise, the shoot length was nearly $27 \mathrm{~cm}$ and $24 \mathrm{~cm}$ in genotypes Aydanhanim, whereas $23 \mathrm{~cm}$ and $13 \mathrm{~cm}$ in genotype Keser under $0 \mu \mathrm{M}$ and $100 \mu \mathrm{M}$ Cd stress respectively (Fig. 3), showing an average reduction of $11 \%$ (Aydanhanim) and $44 \%$ (Keser) with $100 \mu \mathrm{M}$ Cd stress.

Since growth is irreversible, the increase in the mass, weight or volume of a living system, the size and biomass of plant parts are considered as indices of growth performance. Cadmium is known to exert adverse effects on plant growth, especially at early developmental stages (Anjum et al., 2008b; Song et al., 2014), causing growth arrest, wilting, leaf necrosis and root browning (Song et al., 2014). Anatomical and physiological disturbances 


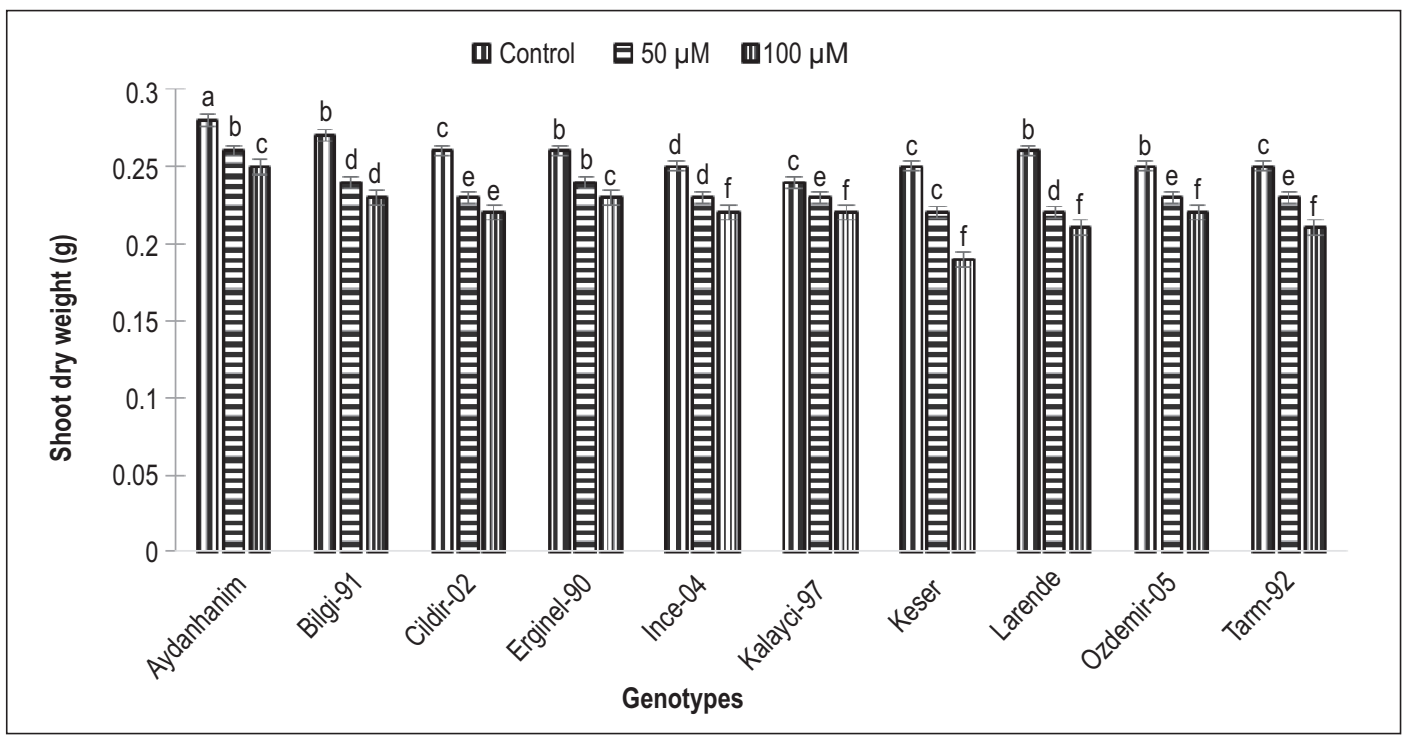

Fig. 5 : Shoot dry weight of 20-day-old seedlings of barley genotypes growing under $\mathrm{Cd}$ stress $(0-100 \mu \mathrm{M})$. All values are means of three independent experiments with three replications each $(n=9)$. Vertical lines indicate $\pm S E$. The bars bearing different letters are statistically different at $p \leq 0.5$, as determined by the Duncan's Multiple Range Test.

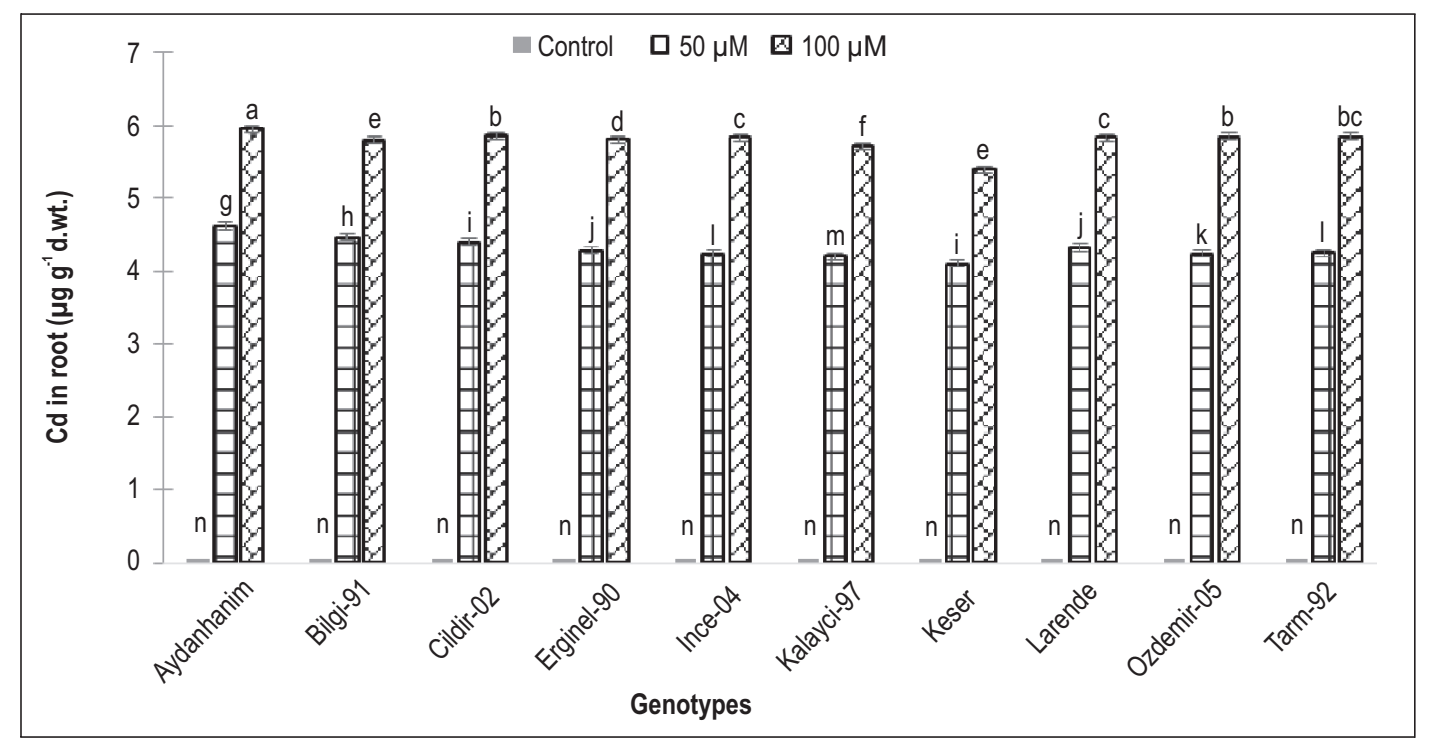

Fig. 6 : Cadmium accumulation in root of 20-day-old seedlings of barley genotypes growing under $\mathrm{Cd}$ stress $(0-100 \mu \mathrm{M})$. All values are means of three independent experiments with three replications each $(n=9)$. Vertical lines indicate $\pm S E$. The bars bearing different letters are statistically different at $p \leq$ 0.5 , as determined by the Duncan's Multiple Range Test.

often lead to growth and yield restrictions (Khudsar et al., 2000, 2001; Munzuroglu and Zengin, 2006). Growth arrest under high Cd stress $(100 \mu \mathrm{M})$ can perhaps be linked to low mitotic activity or restricted cell enlargement due to decreased cellular turgor, as observed earlier in the root-tip meristem of Vigna radiata (Mumthas et al., 2010). The inhibitory effect may also relate to the competition of $\mathrm{Cd}$ with essential metal ions, such as magnesium, iron, copper and zinc in the process of nutrient uptake, thus causing their deficiency in plants, which leads to growth impairment (Ali et al., 1998a, 1998b; El-Kafafi and Rizk, 2013). 


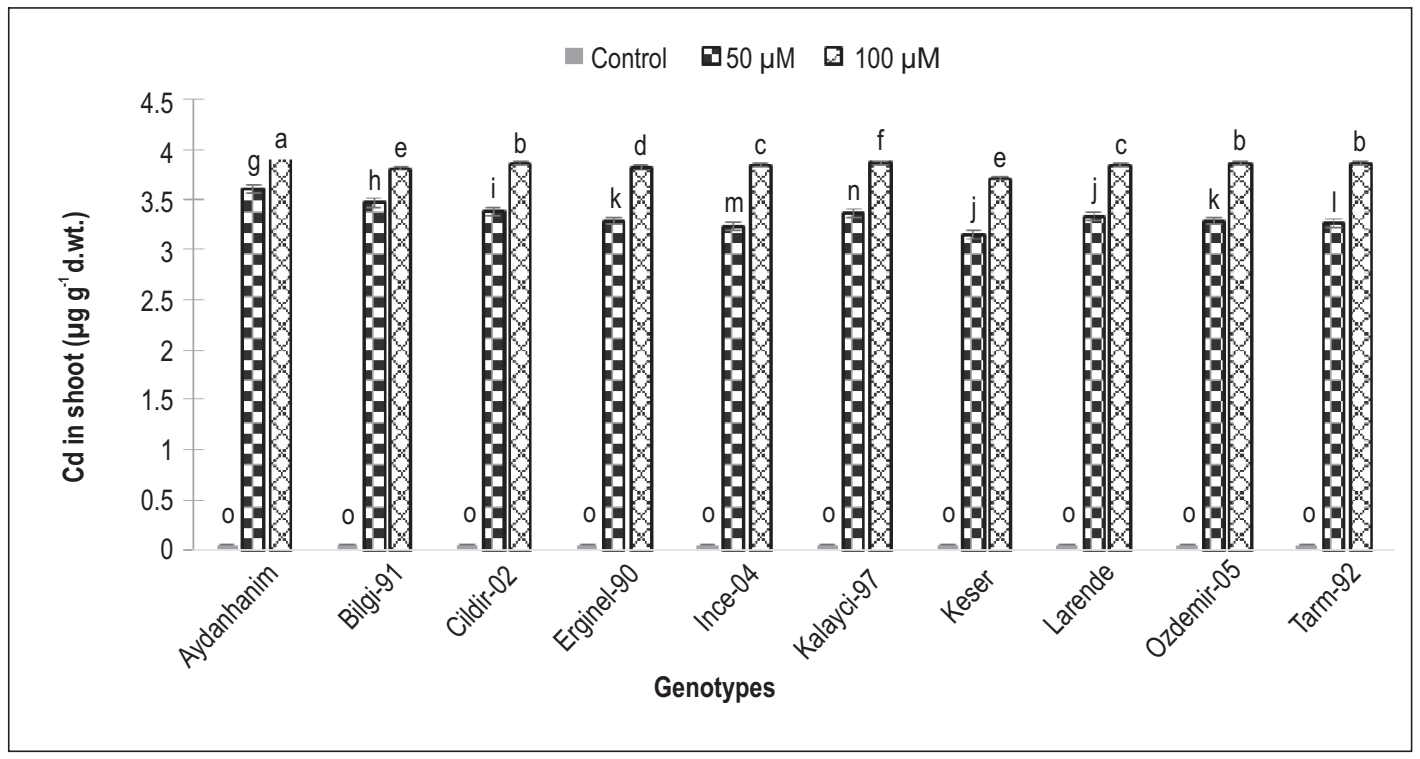

Fig. 7 : Cadmium accumulation in shoot of 20-day-old seedlings of barley genotypes growing under $\mathrm{Cd}$ stress $(0-100 \mu \mathrm{M})$. All values are means of three independent experiments with three replications each $(n=9)$. Vertical lines indicate $\pm S E$. The bars bearing different letters are statistically different at $p \leq$ 0.5 , as determined by the Duncan's Multiple Range Test.

Cadmium application hampered plant biomass (d.wt.) in a concentration-dependent manner, showing the maximum effect at $100 \mu \mathrm{M}$. Root biomass was $0.38 \mathrm{~g}$ and $0.29 \mathrm{~g}$ in Aydanhanim whereas $0.35 \mathrm{~g}$ and $0.22 \mathrm{~g}$ in Keser exposed to $0 \mu \mathrm{M}$ and $100 \mu \mathrm{M}$ Cd, respectively (Fig. 4), which means an average reduction of $19 \%$ (Aydanhanim) to $40 \%$ (Keser) at $100 \mu \mathrm{M}$, compared to the control. In the case of shoot, the biomass was 0.28 and $0.25 \mathrm{~g}$ in Aydanhanim, whereas $0.25 \mathrm{~g}$ and $0.19 \mathrm{~g}$ in Keser, exposed to 0 $\mu \mathrm{M}$ and $100 \mu \mathrm{M} \mathrm{Cd}$ stress, respectively (Fig. 5). The average reduction due to $100 \mu \mathrm{M} \mathrm{Cd}$, therefore, ranged from $11 \%$ (Aydanhanim) to 24\% (Keser) as compared to their respective controls. Our observations conform to some earlier studies on Brassica campestris L., Vigna radiata L., and Lactuca sativa L. (Anjum et al., 2008a; Mumthas et al., 2010; Akhter et al., 2014), among others. A decrease in biomass of plant parts might be due to inhibition of cell division and/or decrease in enzymatic activities (Mehindirata et al., 1999).

$\mathrm{Cd}$ accumulation in roots and shoots of all the barley genotypes studied increased with increase in $\mathrm{Cd}$ concentration in the nutrient solution. In the control samples, all genotypes showed an insignificant and almost equal $\left(0.5 \mu \mathrm{g} \mathrm{g} \mathrm{g}^{-1}\right) \mathrm{Cd}$ concentration both in root and shoot tissues. It increased markedly under 50 and $100 \mu \mathrm{M} C d$ treatments. The genotypic capacity of $\mathrm{Cd}$-accumulation under $100 \mu \mathrm{M}$ stress was variable; ranging from 5.41 to $5.96 \mu \mathrm{g} \mathrm{g}^{-1} \mathrm{~d}$.wt. in roots and 3.71 to $3.94 \mu \mathrm{g}$ $\mathrm{g}^{-1}$ d.wt. in shoots of genotypes Keser and Aydanhanim respectively (Fig. 6 and 7). Thus, both in roots and shoots, the maximum accumulation occurred in Aydanhanim and minimum in Keser (Fig. 6 and 7). Translocation factor, defined as the ratio of
$\mathrm{Cd}$ in shoots to $\mathrm{Cd}$ in roots, varied across the genotypes from 0.73 to 0.79 under $50 \mu \mathrm{M} \mathrm{Cd}$ and from 0.62 to 0.67 under $100 \mu \mathrm{M} \mathrm{Cd}$ treatments (Table 1). The largest translocation factor $(0.79)$ was associated with Aydanhanim at both $\mathrm{Cd}$ treatments, while the lowest was recorded for Özdemir-05 and Tarm-92 at $50 \mu \mathrm{M}$ and $100 \mu \mathrm{M}$ treatments, respectively (Table 1). Cd level was higher in roots than in shoots, indicating that a higher proportion of $\mathrm{Cd}$ taken up by plants was sequestered to roots.

It is expected that the radial movement of $\mathrm{Cd}$ across the root may face some effective barriers such as the cells with the Casparian band. Moreover, in the case of barley, $\mathrm{Cd}$

Table 1 : Translocation factor for ten barley genotypes exposed to 50 and $100 \mu \mathrm{M}$ concentrations of $\mathrm{Cd}$

\begin{tabular}{lll}
\hline & \multicolumn{2}{l}{ Cd concentration $(\boldsymbol{\mu M})$} \\
\cline { 2 - 3 } Genotype & $\mathbf{5 0}$ & $\mathbf{1 0 0}$ \\
\hline Aydanhanim & 0.79 & 0.67 \\
Bilgi-91 & 0.78 & 0.66 \\
Çildir -02 & 0.75 & 0.65 \\
Erginel 90 & 0.77 & 0.64 \\
Ince-04 & 0.76 & 0.66 \\
Kalayci-97 & 0.78 & 0.63 \\
Keser & 0.74 & 0.65 \\
Larende & 0.77 & 0.66 \\
Özdemir-05 & 0.73 & 0.66 \\
Tarm-92 & 0.77 & 0.62 \\
\hline
\end{tabular}


concentration may be higher in the symplast, indicating that barley immobilizes more $\mathrm{Cd}$ via chelation in the root, which would therefore reduce $\mathrm{Cd}$ transfer to shoots (Akhter et al., 2014). Irrespective of the tissue type, most of the $\mathrm{Cd}^{2+}$ developed coordination bonds with $\mathrm{S}_{\text {and }} \mathrm{SO}_{4}$ ligands in the barley roots. Panou-Filotheou and Bosabalidis (2004) opine that plants accumulate a higher $\mathrm{Cd}$ content in their roots than in shoots because roots are the first to contact $\mathrm{Cd}$ intimately, and $\mathrm{Cd}$ has a low mobility within the plant. Roots also provide a protection mechanism targeted at confining the metal perniciousness, thus defending the shoots from toxicity-caused disorders (Ansari et al., 2009).

In conclusion, Turkish genotypes of barley mutually differ in the degree of seed germination, seedling growth and tolerance to $\mathrm{Cd}$ stress. Application of different $\mathrm{Cd}$ concentrations inhibited seed germination, dry mass accumulation and growth variables in barley genotypes, particularly in cv. Keser. A higher amount of $\mathrm{Cd}$ accumulation in the root of genotype Aydanhanim as well as its relatively better growth performance is suggestive of the genetic capability of this genotype to tolerate $\mathrm{Cd}$ stress, and retain and sequester $\mathrm{Cd}$ ions in roots. Thus, genotype Aydanhanim could possibly be used as a phytoremediator of $\mathrm{Cd}$, as it possesses high tolerance potential and is, therefore, less susceptible to $\mathrm{Cd}$ stress. However, the magnitude of the response of this genotype to $\mathrm{Cd}$-stress must be evaluated under field conditions also.

\section{Acknowledgments}

The authors (IMA and MI) appreciate the International Science Partnership Program of King Saud University, Riyadh (Saudi Arabia) for financial assistance towards this study through ISPP \# 00113. The first author (MKAA) thanks the Scientific and Technological Research Council of Turkey for awarding him with the Foreign Citizens Research Fellowship. We also thank the editor and reviewers for their wise suggestions.

\section{References}

Ahmad, S.H., Z. Reshi, J. Ahmad and M. Iqbal : Morpho-anatomical responses of Trigonella foenum-graecum Linn. to induced cadmium and lead stress. J. Plant Biol., 48, 64-84 (2005).

Ahmed, I.M., H. Dai, W. Zheng, F. Cao, G. Zhang, D. Sun and F. Wu: Genotypic differences in physiological characteristics in the tolerance to drought and salinity combined stress between Tibetan wild and cultivated barley. Plant Physiol. Biochem., 63, 49-60 (2013).

Akbulut, N.E. and A.M. Tuncer: Accumulation of heavy metals with water quality parameters in Kızlırmak River Basin (Delice River) in Turkey. Environ. Monit. Assess., 173, 387-395 (2011).

Akhter, M.F., C.R. Omelon, R.A. Gordon, D. Moser and S.M. Macfie: Localization and chemical speciation of cadmium in the roots of barley and lettuce. Environ. Exp. Bot., 100, 10-19 (2014).

Ali, G., M. Iqbal and P.S. Srivastava: Interactive effect of $\mathrm{Cd}$ and $\mathrm{Zn}$ in morphogenic potential of Bacopa monniera (L.) Wettest. Plant Tissue Cult. Biotech., 4, 159-164 (1998a).

Ali, G., P.S. Srivastava and M. Iqbal : Effect of cadmium and copper on growth of Bacopa monniera regenerants. Biol. Plant., 41, 635-639 (1998b).
Ali, G., P.S. Srivastava and M. Iqbal: Influence of cadmium and zinc on growth and photosynthesis of Bacopa monniera cultivated in vitro. Biol. Plant., 43, 599-601 (2000).

Ali, G., P.S. Srivastava and M. Iqbal : Responses of Bacopa monniera cultures to cadmium toxicity. Bull. Environ. Contam. Toxicol., 66, 342-349 (2001).

Anjum, N.A., S. Umar, A. Ahmad and M. Iqbal: Responses of components of antioxidant system in moongbean genotypes to cadmium stress. Commun. Soil Sci. PlantAnaly., 39, 2469-2483 (2008a).

Anjum, N.A., S. Umar, A. Ahmad, M. Iqbal and N.A. Khan : Ontogenic variation in response of Brassica campestris $\mathrm{L}$. to cadmium toxicity. J. Plant Interact., 3, 189-198 (2008b).

Anjum, N.A., S. Umar, M. Iqbal and N.A. Khan : Cadmium causes oxidative stress in mungbean by affecting antioxidant enzyme system and ascorbate-glutathione cycle metabolism. Russ. J. Plant Physiol., 58, 92-99 (2011).

Anjum, N.A., S. Umar and M. Iqbal : Assessment of cadmium accumulation, toxicity and tolerance in Brassicaceae and Fabaceae plants - implications for phytoremediation. Environ. Sci. Pollut. Res., 21, 10286-10293 (2014).

Ansari, M.K.A., A. Ahmad, S. Umar and M. Iqbal: Mercury-induced changes in growth variables and antioxidative enzymes in Indian mustard (Brassica juncea L). J. Plant Interact., 4, 131-136 (2009).

Ansari, M.K.A., A. Ahmad, S. Umar, S.H. Ansari, M. Iqbal, G. Owens and H.B. Shao: Screening Indian mustard genotypes for phytoremediating arsenic-contaminated soil. Clean-Soil Air Water, 41, 195-201 (2013).

Ansari, M.K.A., A. Ahmad, S. Umar, M.H. Zia, M. Iqbal and G. Owens: Genotypic variation in phytoremediation potential of Indian mustard exposed to nickel stress: A hydroponic study. Inter. J. Phytorem., 17, 135-144 (2015).

Bashir, H., M.I. Qureshi, A.M. Ibrahim and M. Iqbal : Chloroplast and photosystems : Impact of cadmium and iron deficiency. Photosynthetica, 53, 321-335 (2015).

Dua, A. and S.K. Sawhney: Effect of chromium on activities of hydrolytic enzymes in germinating pea seeds. Environ. Exp. Bot., 31, 133-139 (1991).

El-Kafafi, E. and A.H. Rizk : Effects of cadmium and combined cadmiumzinc concentrations on rooting and nutrient uptake of cowpea seedlings grown in hydroponic. American-Eurasian J. Agric. Environ. Sci., 13, 1050-1056 (2013).

Fischer, A.B.: Heavy metals in the food chain - lead, cadmium and mercury in foodstuff and population exposures. Proc. Indian Natl. Sci. Acad., B71, 109-143 (2005).

Forster, B.P., R.P. Ellis, W.T.B. Thomas, A.C. Newton, R. Tuberosa, D. This, R. A. El-Enein, M.H. Bahri and M.B. Salem : The development and application of molecular markers for abiotic stresses tolerance in barley. J. Exp. Bot., 51, 19-27 (2000).

Iqbal, M., A. Ahmad, M.K.A. Ansari, M.I. Qureshi, I.M. Aref, P.R. Khan, S.S. Hegazy, H. El-Atta, A. Husen and K.R. Hakeem : Improving the phytoextraction capacity of plants to scavenge metal (loid)contaminated sites. Environ. Rev., 23, 44-65 (2015).

Jaouani, K., I. Karmous, M. Ostrowski, E. El Ferjani, A. Jakubowska and A. Chaoui: The responses of embryos to cadmium-induced oxidative stress in germinating pea seeds. Res. J. Biol., 4, 39-45 (2016).

Kalai, T., K. Khamassi, J.A. Teixeira da Silva, H. Gouia and L.B. BenKaab: Cadmium and copper stress affect seedling growth and enzymatic activities in germinating barley seeds. Arch. Agro. Soil Sci., 6, 765-783 (2014).

Khudsar, T., Mahmooduzzafar, W.Y. Soh and M. Iqbal : Morphological and anatomical variations of Cajanus cajan (Linn.) Huth raised in cadmium-rich soil. J. Plant Biol., 43, 149-157 (2000).

Khudsar, T., Mahmooduzzafar and M. Iqbal: Cadmium-induced change 
in leaf epidermes, photosynthetic rate and pigment concentrations in Cajanus cajan. Biol. Plant., 44, 59-64 (2001).

Kuriakose, S.V. and M.N.V. Prasad: Cadmium stress affects seed germination and seedling growth in Sorghum bicolor (L.) Moench by changing the activities of hydrolyzing enzymes. Plant Growth. Regul., 54, 143-156 (2008).

Long, X., N. Ni, W. Lin, W. Xuheng, W. Jinxing, Z. Zhenhua, Z. Rengel, L. Zhaopu and B.S. Hong : Phytoremediation of cadmiumcontaminated soil by two Jerusalem Artichoke (Helianthus tuberosus L.) genotypes. Clean - Soil Air Water, 41, 202-209 (2013).

Mahmood, A. : A new rapid and simple method of screening wheat plants at early stage of growth for salinity tolerance. Pak. J. Bot., 41, 255262 (2009).

Mahmood, Q., A. Rashid, S.S. Ahmad, M.R. Azim and M. Bilal: Current status of toxic metals addition to environment and its consequences. In: The Plant Family Brassicaceae - Contribution towards Phytoremediation (Eds : N.A. Anjum, I. Ahmad, M.E. Pereira, A.C. Duarte, S. Umar and N.A. Khan), Springer Science + Business Media, Dordrecht, pp. 35-69 (2012).

Mehindirata, S., S.T. Ali, Mahmooduzzafar, T.O. Siddiqi and M. Iqbal: Cadmium-induced changes in foliar responses of Solanum melongena L. Phytomorphology, 49, 295-302 (1999).

Mehindirata, S., Mahmooduzzafar, T.O. Siddiqi and M. Iqbal : Cadmiuminduced changes in growth and structure of root and stem of Solanum melongena L. Phytomorphology, 50, 243-251 (2000).

Mobin, M.: Effects of cadmium-induced oxidative stress on growth and nitrogen assimilation in Blackgram [Vigna mungo (L.) Hepper]. J. Agric. Sci., 58, 31-39 (2013).

Mumthas, S, A.A. Chidambaram, P. Sundaramoorthy and K.S. Ganesh: Effect of arsenic and manganese on root growth and cell division in root tip cells of green gram (Vigna radiata L.). J. Food Agric., 22, 285-297 (2010).

Müntz, K., M.A. Belozersky, Y.E. Dunaevsky, A. Schlereth and J. Tiedemann : Stored proteinases and the initiation of storage protein mobilization in seeds during germination and seedling growth. J. Exp. Bot., 52, 1741-1752 (2001).

Munzuroglu, $\mathrm{O}$. and $\mathrm{H}$. Geckil : Effects of metals on seed germination, root elongation, and coleoptile and hypocotyl growth in Triticum aestivum and Cucumis sativus. Arch. Environ. Contam. Toxicol., 43, 203-213 (2002)

Munzuroglu, O. and F.K. Zengin: Effect of cadmium on germination, coleoptile and root growth of barley seeds in the presence of gibberellic acid and kinetin. J. Environ. Biol., 27,671-677 (2006).

Nagajyoti, P.C., K.D. Lee, T.V.M. Sreekanth : Heavy metals, occurrence and toxicity for plants : A review. Environ. Chem. Let., 8, 199-216 (2010).

Nazar, R., N. Iqbal, A. Masood, M.I.R. Khan, S. Syeed and N.A. Khan : Cadmium toxicity in plants and role of mineral nutrients in its alleviation. Amer. J. Plant Sci., 3, 1476-1489 (2012).

Panou-Filotheou, H. and A.M. Bosabalidis : Root structural aspects associated with copper toxicity in Oregano (Origanum vulgare subsp. hirtum). Plant Sci., 166, 1497-1504 (2004).

Piper, C.S.: Investigations on copper deficiency in plants. J. Agric. Sci., $32,143-148(1942)$.

Rajjou, L., M. Duval, K. Gallardo, J. Catusse, J. Bally, C. Job and D. Job : Seed germination and vigor. Annu. Rev. Plant Biol., 63, 507-533 (2012).

Salt, D.E., M. Blaylock, P.B.A.N. Kumar, V. Dushenkov, B.D. Ensley, L. Chet and L. Raskin: Phytoremediation : A novel strategy for the removal of toxic metals from the environment using plants. Biotechnology, 13, 468-474 (1995).

Sfaxi-Bousbih, A., A. Chaoui and E. El-Ferjani : Cadmium impairs minerals and carbohydrate mobilization during the germination of bean seeds. Ecotoxicol. Environ. Saf., 73, 1123-1129 (2010).

Smiri, M., A. Chaoui and El-Ferjani : Respiratory metabolism in the embryonic axis of germinating pea seed exposed to cadmium. $J$. Plant Physiol., 166, 259-269 (2009).

Song, W.Y., H.C. Yang, H.B. Shao, A.Z. Zheng and M. Brestic: The alleviative effects of salicylic acid on the activities of catalase and superoxide dismutase in malting barley (Hordeum valgare L.) seedling leaves stressed by heavy metals. Clean - Soil Air Water, 42, 88-97 (2014).

Vassilev, A., T. Tsonev and I. Yordanov : Physiological response of barley plants (Hordeum vulgare) to cadmium contamination in soil during ontogenesis. Environ. Pollut., 103, 287-293 (1998).

Wang, L.K., J.P. Chen, Y-T. Hung and N.K. Shammas : Heavy Metals in the Environment. CRC Press (2017). 